\title{
The presence of Abronia oaxacae (Squamata: Anguidae) in tank bromeliads in temperate forests of Oaxaca, Mexico
}

\author{
Cruz-Ruiz,GI., Mondragón, D. and Santos-Moreno, A. * \\ Instituto Politécnico Nacional - IPN, Centro Interdisciplinario de Investigación para el \\ Desarrollo Integral Regional Unidad Oaxaca - CIIDIR, Calle Hornos, 1003, \\ Santa Cruz Xoxocotlán, CP 71230, Oaxaca, México \\ *e-mail: asantosm90@ hotmail.com
}

Received June 13, 2011 - Accepted August 2, 2011 - Distributed May 31, 2012

(With 2 figures)

\begin{abstract}
The presence of lizards in bromeliads has been widely documented. Nevertheless, the possibility of some type of preference or specificity among lizards for particular bromeliad species has not yet been investigated. Therefore, this study aims to document the presence of Abronia oaxacae in six species of tank bromeliads found in pine forests, pine-live oak forests, and live oak groves during both the rainy season and the dry season. Three adult individuals of Abronia oaxacae were collected; one in a Tillandsia violácea (pine-live oak forest), one in a T. calothyrsus (live oak grove), and one in a T. prodigiosa (live oak grove). All three specimens were collected in sampling efforts carried out during the dry season. The results of the present study suggest that $A$. oaxacae shows no preference for a single, specific bromeliad species, although it does have a certain preference for a few select species. The presence of A. oaxacae in bromeliads during the dry season could be related to the cooler, moister microhabitat that these plants represent.
\end{abstract}

Keywords: Mexico, microhabitat, Oaxaca, reptiles, temperate forest.

\section{A presença de Abronia oaxacae (Squamata: Anguidae) em bromélias tanque em florestas temperadas de Oaxaca, México}

\begin{abstract}
Resumo
A presença de lagartos em bromélias tem sido amplamente documentada, no entanto, a possibilidade de algum tipo de preferência ou especificidade entre os lagartos para determinadas espécies de bromélias ainda não foi investigada. Portanto, este estudo tem como objetivo documentar a presença de Abronia oaxacaeem seis espécies de bromélias tanque encontrado em pinhais, matas de pinheiro e carvalho vivo, e os bosques de carvalho vivo, durante a estação chuvosa ea estação seca. Três indivíduos adultos de Abronia oaxacaeforam coletados, um em Tillandsia violácea (floresta de pinheiro e carvalho ao vivo), um em T. calothyrsus(bosque de carvalhos vivos), e um em T. prodigiosa (bosque de carvalhos vivos). Todas as três amostras foram coletadas em amostragem esforços realizados durante a estação seca. Os resultados do estudo sugerem que $A$. oaxacaenão apresenta preferência por um único, específico espécies de bromélias, apesar de não apresentar certa preferência por algumas espécies selecionadas. A presença de A. oaxacae em bromélias durante a estação seca pode estar relacionada com o condições úmidas e frias oferecidas por estas plantas.
\end{abstract}

Palavras-chave: México, microhabitat, Oaxaca, répteis, floresta temperada. 


\section{Introduction}

Tank bromeliads, which as a result of their rosettes are capable of storing water and detritus between their leaves, have been considered diversity amplifiers due to the large number of interactions they establish with various organisms, ranging from algae, protozoa, and insects to reptiles, birds and small mammals. These organisms use tank bromeliads as a source of water, food, and/or refuge (Benzing, 1990; Nadkarni, 1994; Mondragón-Chaparro and Cruz-Ruiz, 2009).Some organisms show a marked specificity towards some bromeliad species (Romero, 2006), although most only show some preference and are mostly generalists (Richardson et al., 2000; Stuntz, 2001).

Although the presence of lizards inside tank bromeliads has been widely documented in Brazilian restingas and the lizard species which uses this type of bromeliads has been observed to have morphological differences in comparison with other lizards such as Hemidactylus mabouia (Moreau de Jonnés, 1818), Gymnodactylus darwinii (Gray, 1845), Mabuya macrorhyncha and Mabuya agilis (Raddi, 1823; Vrcibradic and Rocha, 1996; Teixeira-Filho et al., 2001; De Carvallo and De Araújo, 2007), none of the aforementioned studies makes reference to the specificity or generality of preference for specific bromeliad species. Most refer simply to "bromeliads," without specifying the species observed.

In Mexico, the presence of several lizard species of the genus Abronia has been reported in tank bromeliads growing in pine-live oak forests (Bogert and Porter, 1967; Campbell and Frost, 1993) in the Sierra Norte and Sierra Sur mountain ranges in the states of Oaxaca and Chiapas (Campbell, 1984; Campbell and Frost, 1993). Nevertheless, these studies were essentially focused on describing the lizard species and not on examining the interaction between the lizards and the bromeliad species in which they were found.

Such is the case of $A$. oaxacae (Günther, 1885) (Squamata: Anguidae), which has been reported inside bromeliads in the pine-live oak forests of the El Punto locality, in the municipality of Santa Catarina Ixtepeji, located in the Sierra Norte mountain range in the state of Oaxaca, Mexico. At least six species of tank bromeliads can be found in this municipality. Thus, with the aim of studying their possible preference for a certain type of bromeliad species, this study was conducted to report the presence of $A$. oaxacae individuals in the tank bromeliad community present in three ecosystem types, taking into account whether the presence of these lizards varies throughout the dry and rainy seasons.

\section{Material and Methods}

The study was carried out in the municipality of Santa Catarina Ixtepeji, in the Sierra Norte mountain range of the state of Oaxaca, Mexico (Figure 1). The types of vegetation studied were as follows: a) Pine forest: located at $2870 \mathrm{~m}$ above sea level, coordinates $17^{\circ} 09^{\prime} \mathrm{N}$ and $-96^{\circ} 38^{\prime} \mathrm{W}$. The vegetation is a pine forest, with elements of de Quercus laurina Bonpl., Q. rugosa Née, and Arbutus aff. xalapensis. The epiphytic flora is made up of orchids, ferns, bromeliads, and piperaceae. The epiphytic bromeliad species of the area are: Tillandsia carloshankii Matuda, T. macdougalli L. B. Sm., T. violacea Baker, T. quaquaflorifera Matuda, and T. oaxacana L. B. Sm. (Mondragón et al., 2006). b) Pine-live oak forest: coordinates $17^{\circ} 13^{\prime} \mathrm{N}$ and $-96^{\circ} 35^{\prime} \mathrm{W}$, at $2547 \mathrm{~m}$ above sea level. The vegetation present in this ecosystem is considered to be an association between pines and live oaks, with some species of Pinus, A. aff. xalapensis, $Q$. rugosa, $Q$. aff. acutifolia, and $Q$. laurina. The epiphytic flora is essentially made up of bromeliads, ferns, and orchids. The species of epiphytic bromeliads found in the area are: Tillandsia bourgaei Baker, T. carloshankii Matuda, T. macdougallii L. B. Sm., T. violacea Baker and T. prodigiosa (Lem.) Baker. (Mondragón et al., 2006). c) Live oak forest: coordinates $17^{\circ} 14^{\prime} \mathrm{N}$ and $-96^{\circ} 33^{\prime} \mathrm{W}$, at $2300 \mathrm{~m}$ above sea level. Vegetation consists of Quercus castanea Née, Q. obtusata Bonpl., Q. rugosa, Q. laurina, Q. magnoliifolia Née, and Q. laeta Liebm., with some species of Pinusand Arbutus aff. xalapensis. The epiphytic flora is made up of a wide variety of orchids, ferns, and bromeliads. The epiphytic bromeliad species present in this area are: Catopsis berteroniana (Schult. and Schult. f) Mez, Tillandsia bourgaei Baker, T. calothyrsus Mez, T. juncea (Ruíz and Pav.) Poir., T. magnusiana Wittm., T. prodigiosa (Lem.) Baker, T. usneoides (L.) L., and Viridantha plumosa (Baker) Espejo (Mondragón et al., 2006).

Taking advantage of the sampling effort carried out as part of a project to determine the macroarthropods present in the epiphytic bromeliad community in the three types of vegetation mentioned above, the presence of lizards in these three localities was recorded. The Campbell and Frost dichotomous key (1993) was used to identify the specimens. Sampling took place between September of 2005 and April of 2008. Each bromeliad was placed in a plastic bag and transported to the laboratory, where the leaves were removed in search of macroarthropods. This offered the opportunity at the same time to collect the lizard individuals present in the bromeliad specimens.

\section{Results}

Five samples were taken and a total of 305 epiphytic tank bromeliad samples of six species were collected (Table 1). Throughout the sampling period, only three lizards were found, all identified as Abronia oaxacae. One was found in a T. violaceae (pine-live oak forest), one in a T. prodigiosa (live oak grove), and the last one was found in a $T$. calothyrsus (live oak grove). This constitutes the first record of A. oaxacae in this type of vegetation, as it had previously only been reported in pine-live oak forests (Bogert and Porter, 1967). 


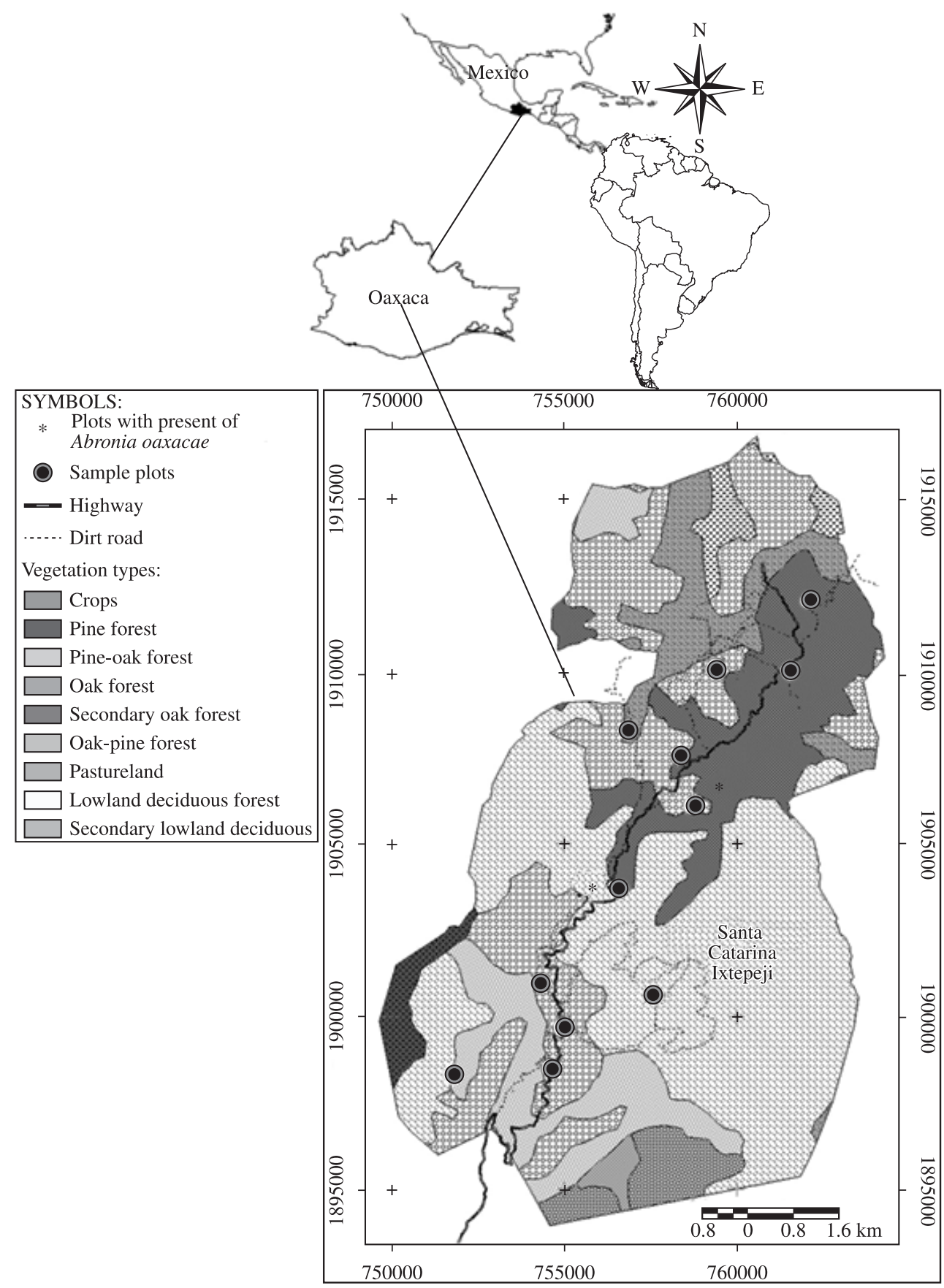

Figure 1. Map showing the sampling plots and vegetation types in Santa Catarina Ixtepeji, Oaxaca, Mexico.

\section{Discussion}

The presence of lizards in tank bromeliads has been related to the availability of food (Campbell and Frost, 1993; Teixeira-Filho et al., 2001) or of refuge (De Carvalho and De Araujo, 2007). In the case of A. oaxacae, its presence may be related to the availability of food, as well as bodies of water given that the presence of numerous macroarthropod individuals living inside tank bromeliads has been documented in both pine-live oak forests and live oak groves, especially during the dry season (García, 2008; Mondragon and Cruz, 2008). In addition, the presence of Abronia inside bromeliads could be attributed to the suitability of these plants as a refuge from the heat and aridity that predominate during the dry season in the aforementioned ecosystems, where the temperature and 
Table 1. Number of tank bromeliad specimens collected per season and vegetation type $(\mathrm{P}=\mathrm{Pine}$ Forest; $\mathrm{P}-\mathrm{O}=\mathrm{Pine}$ Forest - Live Oak Grove, and O = Live Oak Grove), in Santa Catarina Ixtepeji, Oaxaca, Mexico from September 2005 to April 2008.

\begin{tabular}{|c|c|c|c|c|c|c|c|c|c|c|c|c|c|c|c|c|}
\hline \multirow{3}{*}{$\begin{array}{c}\text { Bromeliad } \\
\text { Species }\end{array}$} & \multicolumn{15}{|c|}{ Season } & \multirow{3}{*}{ Total } \\
\hline & \multicolumn{3}{|c|}{ Rainy 2005} & \multicolumn{3}{|c|}{ Dry 2006} & \multicolumn{3}{|c|}{ Rainy 2006} & \multicolumn{3}{|c|}{ Dry 2007} & \multicolumn{3}{|c|}{ Rainy 2008} & \\
\hline & $\mathbf{P}$ & P-O & $\mathbf{O}$ & $\mathbf{P}$ & P-O & O & $\mathbf{P}$ & P-O & $\mathbf{O}$ & $\mathbf{P}$ & P-O & $\mathbf{O}$ & $\mathbf{P}$ & P-O & $\mathbf{O}$ & \\
\hline Tillandsia prodigiosa & 0 & 10 & 10 & 0 & 10 & 10 & 0 & 10 & 10 & 0 & 10 & 7 & 0 & 0 & 0 & 77 \\
\hline Tillandsia carlos-hankii & 10 & 8 & 0 & 10 & 10 & 0 & 10 & 0 & 0 & 10 & 0 & 0 & 0 & 0 & 0 & 58 \\
\hline Tillandsia bourgaei & 0 & 0 & 0 & 0 & 0 & 11 & 0 & 0 & 10 & 0 & 0 & 9 & 0 & 0 & 0 & 30 \\
\hline Tillandsia calothyrsus & 0 & 0 & 3 & 0 & 0 & 10 & 0 & 0 & 9 & 0 & 0 & 10 & 0 & 0 & 20 & 52 \\
\hline Tillandsia oaxacana & 10 & 0 & 0 & 10 & 0 & 0 & 10 & 0 & 0 & 10 & 0 & 0 & 0 & 0 & 0 & 40 \\
\hline Tillandsia violacea & 9 & 0 & 0 & 10 & 0 & 0 & 9 & 0 & 0 & 10 & 0 & 0 & 0 & 10 & 0 & 48 \\
\hline Total & 29 & 18 & 13 & 30 & 20 & 31 & 29 & 10 & 29 & 30 & 10 & 26 & 0 & 10 & 20 & 305 \\
\hline
\end{tabular}

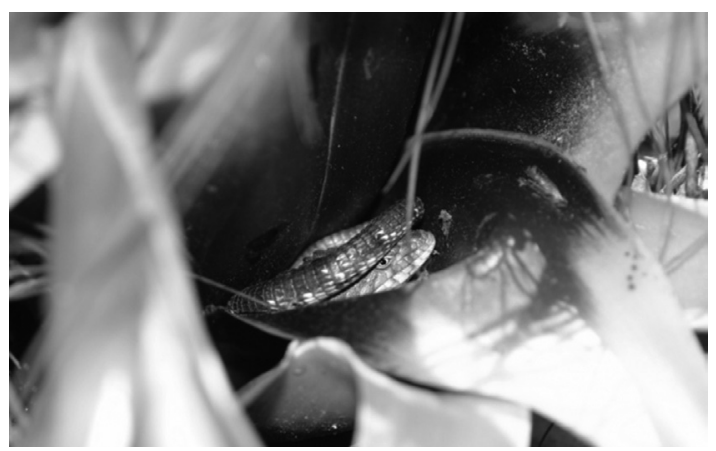

Figure 2. Abronia oaxacae inside the epiphytic bromeliad Tillandsia violácea, in the La Petenera site in El Punto, Santa Catarina Ixtepeji, Ixtlán, Oaxaca, Mexico.

incidence of light may increase considerably due to the deciduous nature of many of the live oaks in the area. The difference in temperature between exposed branches and branches close to bromeliads may reach up to four degrees centigrade, the same as the difference between the temperature on exposed branches and the temperature within the bromeliads (Stuntz et al., 2002). The Abronia specimens collected in this study were found deep within the leaves of the bromeliads, and were rolled up (Figure 2).

The presence of A. oaxacae in three different species of bromeliad suggests that there is no specificity for a single bromeliad species on the part of the lizards. Nevertheless, their presence in three of the six bromeliad species evaluated suggests a certain preference for the occupied species. This preference may be related to the size and depth of the cavities between the leaves of said species, as due to their size, A. oaxacae individuals require a certain amount of space to insert themselves.

Finally, the low number of A. oaxacae individuals found throughout the three years of sampling may be related to the fact that this species of lizard, catalogued as arboreal, makes only occasional use of bromeliads. During this study it was observed on the ground, on the trunks of pine trees, and hidden between patches of Piperaceae growing on a pine tree. It seems that the use of various microhabitats throughout the day is a common behavior in lizards. Such is the case of Mabuya agilis (Raddi) in Brazilian restingas, which makes use of the ground, cacti, bromeliads, palm trees, and bushes (Vrcibradic and Rocha, 2002).

Acknowledgements - The authors are grateful to the Consejo Nacional de Ciencia y Tecnología-CONACYT (Mexico) for funding the "Diversity, Floral Phenology, and Animal-Plant Interactions of Epiphytic Bromeliads Present Throughout the Altitudinal Gradient of the Live Oak Pine Forest of Ixtepeji, in the Sierra Norte de Oaxaca" project (SEP-2004-CO1-43136). They would also like to thank COFFA at the Instituto Politécnico Nacional-IPN (Mexico).

\section{References}

BENZING, DH., 1990. Vascular epiphytes. New York: Cambridge University Press.

BOGERT, CM. and PORTERAP.,1967. A new species of Abronia (Sauria, Anguidae) from the Sierra Madre del Sur of Oaxaca, Mexico. American Museum Novitiates, vol. 2279, p. 1-21.

CAMPBELL, JA.,1984. A new species of Abronia (Sauria: Anguidae) with comments on the herpetogeography of the highlands of southern Mexico. Herpetologica, vol. 40, no. 4, p. 373-381.

CAMPBELL, JA. and FROST, DR., 1993. Anguid lizard of the genus Abronia: reversionary notes, descriptions of four new species, a phylogenetic analysis, and key. Bulletin of the American Museum of Natural History, vol. 126, p. 101-111.

DE CARVALHO, ALG. and DE ARAÚJO, AFB., 2007. Ecomorphometric structure of Restinga da Marambaia lizard community, Rio de Janeiro, southeastern Brazil. Revista Brasileira de Zoología = Brazilian Journal of Biology, vol. 24, no. 3, p. 786-792.

GARCÍA, IM., 2008. Macroártropodos asociados a la bromelia Tillandsia prodigiosa (Lem.) Baker en dos localidades de Santa Catarina Ixtepeji, Oaxaca. Oaxaca: Centro Interdisciplinario de Investigación para el Desarrollo Integral Regional Unidad. Disseração de Mestrado.

MONDRAGÓN, D., RAMÍREZ, IMM., VILLA, DMG., ESCOBEDO, GJS., and FRANCO, ADF., 2006. La riqueza de bromelias epífitas a lo largo de un gradiente altitudinal en Santa 
Catarina Ixtepeji, Oaxaca, México. IPN - Naturaleza y Desarrollo, vol. 4 , no. 2, p. 1-21.

MONDRAGÓN-CHAPARRO, DM., and CRUZ-RUIZ, GI., 2009. Seasonal variation of the macro-arthropod community associated to Tillandsia carlos-hankii (Bromeliaceae) in an oak-pine forest in Oaxaca, Mexico. Brenesia, vol. 70, p. 11-22.

NADKARNI, NM., 1994. Diversity of species and interactions in the upper tree canopy of forest ecosystems. American Zoologits, vol. 34, p. 70-78.

RICHARDSON, BA., ROGERS, C., and RICHARDSON, MJ., 2000. Nutrients, diversity, and community structure of two phytotelm systems lower montane forest, Puerto Rico. Ecological Entomology, vol. 25, p. 348-356. http://dx.doi.org/10.1046/j.13652311.2000.00255.x

ROMERO, GQ., 2006. Geographic range, habitat, and host plants of bromeliad-living jumping spiders. Biotropica, vol. 38, p. 522-530. http://dx.doi.org/10.1111/j.1744-7429.2006.00173.x
STUNTZ, S., 2001. The influence of epiphytes on arthropods in thetropical forest canopy. Wüuzburg: University of Wüuzburg. Tese de Doutorado.

STUNTZ, S., SIMON, U., and ZOTZ, G., 2002. Rainforest air-conditioning: the moderating influence of epiphytes on the microclimate in tropical tree crowns. Journal of Biometeorology, vol. 46, p. 53-59. PMid:12135199. http://dx.doi.org/10.1007/ s00484-001-0117-8

TEIXEIRA-FILHO, P., ROCHA-BARBOSA, O., PAES, V., CARVALHO, S., and DE ALMEIDA, JR., 2001. Ecomorphological relationships in six lizard species of restinga da barra de Maricá, Río de Janeiro, Brazil. Revista Chilena de Anatomía, vol. 19, no. 1, p. $45-50$

VRCIBRADIC, D. and ROCHA, CFD., 1996. Ecological differences in tropical sympatric skinks (Mabuya macrorhyncha and Mabuya agilis) in southeastern Brazil. Journal of Herpetology, vol. 30, no. 1, p. 60-67. http://dx.doi.org/10.2307/1564707 
